Meta

Journal des traducteurs

Translators' Journal

\title{
Of Whales and Savages
}

Reflections on Translating Louis Nicolas' Histoire naturelle des

Indes occidentales

\section{Nancy Senior}

Volume 49, numéro 3, septembre 2004

L'histoire de la traduction et la traduction de l'histoire

History of Translation and Translation of History

URI : https://id.erudit.org/iderudit/009372ar

DOI : https://doi.org/10.7202/009372ar

Aller au sommaire du numéro

\section{Éditeur(s)}

Les Presses de l'Université de Montréal

ISSN

0026-0452 (imprimé)

1492-1421 (numérique)

Découvrir la revue

Citer cet article

Senior, N. (2004). Of Whales and Savages: Reflections on Translating Louis Nicolas' Histoire naturelle des Indes occidentales. Meta, 49(3), 462-474.

https://doi.org/10.7202/009372ar

\section{Résumé de l'article}

L'Histoire naturelle des Indes occidentales de Louis Nicolas, oeuvre inédite de la fin du XvII ${ }^{\mathrm{e}}$ siècle, décrit des espèces naturelles de Nouvelle-France et plusieurs pratiques des peuples autochtones. En la traduisant on fait face à des questions de langue (mots et expressions dont le sens a changé), d'histoire naturelle (identification des espèces de plantes, d'animaux, d'oiseaux et de poissons), et de rapports sociaux. Dans les allusions aux peuples autochtones, on peut se demander comment traiter des mots tels que "sauvage " et " barbare », dont le mot analogue en anglais évoque des idées différentes.
Ce document est protégé par la loi sur le droit d'auteur. L'utilisation des services d'Érudit (y compris la reproduction) est assujettie à sa politique d'utilisation que vous pouvez consulter en ligne.

https://apropos.erudit.org/fr/usagers/politique-dutilisation/ 


\title{
Of Whales and Savages. Reflections on Translating Louis Nicolas' Histoire naturelle des Indes occidentales'
}

\author{
NANCY SENIOR \\ University of Saskatchewan, Saskatoon, Canada \\ seniorn@duke.usask.ca
}

\begin{abstract}
RÉSUMÉ
L'Histoire naturelle des Indes occidentales de Louis Nicolas, œuvre inédite de la fin du $\mathrm{XVII}{ }^{\mathrm{e}}$ siècle, décrit des espèces naturelles de Nouvelle-France et plusieurs pratiques des peuples autochtones. En la traduisant on fait face à des questions de langue (mots et expressions dont le sens a changé), d'histoire naturelle (identification des espèces de plantes, d'animaux, d'oiseaux et de poissons), et de rapports sociaux. Dans les allusions aux peuples autochtones, on peut se demander comment traiter des mots tels que «sauvage» et «barbare», dont le mot analogue en anglais évoque des idées différentes.
\end{abstract}

\begin{abstract}
The Histoire naturelle des Indes occidentales by Louis Nicolas, an unpublished late seventeenth-century work, describes natural species in New France and many practices of native people. Translating it involves questions of language (words and expressions that have changed meaning), natural history (identifying species of plants, animals, birds and fish), and social relations. References to native people raise questions about how to deal with words such as sauvage and barbare, where the cognate word in English has different connotations from the French word.
\end{abstract}

\section{MOTS-CLÉS/KEYWORDS}

Louis Nicolas, Histoire naturelle, Codex Canadiensis, savage

Translating a text written several hundred years ago almost always involves questions about how language has changed in the centuries between composition and translation. In the case of a book-length document describing plants, animals and people of the New World, other kinds of questions, including scientific and ethnographic ones, arise in addition to linguistic concerns.

The document in question is the Histoire naturelle des Indes occidentales, written by Louis Nicolas, a Jesuit missionary who was in New France from 1664 to 1675. In addition to this work, Nicolas is the author of a grammar of the Algonquin language, recently published for the first time (Nicolas 1994; see also Hanzeli 1969), of the Traité des animaux, which is a first draft of the Histoire naturelle, and of the Raretés des Indes, also known as the Codex Canadiensis, a book of drawings of plants, animals, birds, fish and people from New France. The Codex was long mistakenly attributed to Charles Bécard, Sieur de Grandville. Only in the latter part of the twentieth century was it discovered that a manuscript on natural history in the Bibliothèque Nationale de France was related to the much better-known Codex, and that the author of both was Louis Nicolas. (Sioui 1979) An English translation of the Histoire naturelle is now being prepared for publication. ${ }^{2}$ 
The Histoire naturelle is divided into four parts, which treat respectively plants, animals (specifically quadrupeds), birds and fish. The classification is based not only on their anatomy but also on their habitat, an equally or in some cases a more important criterion for Nicolas. ${ }^{3}$ He discusses the way native people use the plants or animals and how they hunt and fish. His digressions, which were not appreciated by his superiors (Tremblay 1983), are among the most interesting parts of the work for the reader today.

Two contrasting approaches to translating such a document are possible. The translator can adhere to the wording of the original as closely as possible while producing a comprehensible text. On the other hand, one can depart more or less freely from the original wording in order to transmit, to a target-language reader, what the translator takes to be the meaning. Advocates of both approaches defend their preference by appealing to the value of fidelity to the source text, a fidelity which they see in different ways. Some prefer to set the translator free from the wording of the original in order better to transmit its underlying sense, or to produce, for a public contemporary with the translator, an impression comparable to that which was produced by the original work. This view is held by Nida, especially in the context of biblical translation (e.g. Nida 1964), and by Seleskovich in her studies of translation and interpretation (e.g. Seleskovitch and Lederer 1984). Implications of this approach for internationalization were studied at the 2003 Congress of the Canadian Society of Translation Studies, which examined ways in which pragmatic translations such as those for business and advertising are adapted for different target audiences. In contrast, particularly in the context of literary works, some writers object to what they judge to be over-adaptation; they consider that the serious reader should be willing to make the effort necessary to understand a different way of thinking. See Schleiermacher's famous essay (Schleiermacher 1977), and Berman's view that readers should test their view against a foreign one (Berman 1992). In practice, translators often adopt some mixture of these two approaches, depending on the particular text or passage being translated and the reading public envisaged. ${ }^{4}$ Occasionally they insert brief explanations for what they fear may be unclear to the reader. ${ }^{5}$

In the case of the Histoire naturelle, a text-based rendering is appropriate, by the nature of the work and its historical interest. The question of adaptation to an audience arises rarely, although a particular point will be discussed below. Most of the text consists of descriptions of species, but other material is included, digressions are frequent, and the author at times indulges in rhetorical effects.

Nicolas's sentences are sometimes long and hard to follow, and on occasion there are even ungrammatical ones where presumably the author lost track. In his discussion of le citron (a plant different from what is normally called "lemon," but bearing similar-looking fruit), he writes: ${ }^{6}$

Pour vous dire maintenant pour quoy j'ay si bien fait la description de cette plante, cet qu'il faut sçavoir q'un iour mettant égaré avec un seul françois dans les bois, et dans les vastes prairies de la Virginie ou le foin y étoit presque de la hauteur d'un quart de pique et y mourant de faim avec ce cher camarade qui leiour auparavant que je rencontrasse des citrons mettoit tombé 2 fois endefaillance dans le chemin mourant de faim ayant soufert déia quelques iours sans beaucoup manger et ayant passé une nuit sur le bord d'une ecluse de castor couchés a platte terre sans nulle couverture, et sans vivres. Lelandemain nous trainant miserablement dans les bois pour tacher de nous remettre 
dans nôtre route nous tombames heureusement dans un grand fonds de bois et ensuite dans des prairies a perte de veue que nous avions veu du haut d'une montagne, Nous trouvames des citrons que je decrits icy avec des moeures de buisson, nous en mangeames beaucoup et enfimes provision pour quelques iours. (folio 11$)^{7}$

In the greater part by far of the document, we follow Nicolas' sentence structure closely, making only those changes necessary for comprehension.

Questions may arise at the level of the word as well as that of the sentence. Geographical features that had different names in the seventeenth century can be called by Nicolas's term in the text, and identified when necessary - and possible - by a footnote. Nicolas identifies la mer Tracy as the "grand lac Supérieur," but the lakes "de Saint-Pierre, de Saint-Louis, de Saint-François, de Saint-Jean, du Saint-Sacrement," as well as le lac Puant and many others, are less obvious. The case of la mer Illande has an interesting twist. This "Illande Sea" is what is now called Chesapeake Bay, the name used by Nicolas apparently being a misunderstanding of the name "Maryland."

As we all know, with time the meanings of words and of constructions change. The fact that some meanings of a word are different while others remain the same can pose problems for translators. One of Nicolas' favourite adjectives is rare. All sorts of things are rare; indeed the subtitle of the Histoire naturelle promises "tout ce qu'il y a de rare dans les Indes occidentales." Usually for him the word is a general term of praise: The traveller will find "mille petites raretés" along the shores of the Great Lakes (f. 2). The fruit that he calls the pomme de terre "n'a rien de rare que sa beauté" (f. 18). ${ }^{8}$ Some arrows made of bois puant, when taken back to France, were considered to be "fort rares" (f. 26). White cedar has "une écorce fort rare" of four different colours (f. 44). Sometimes the word is used in the usual present-day sense of unusual or hard to find: The oranger américain is "un arbrisseau rare, qu'on ne voit que dans la Virginie, le long du fleuve de Techiroguen" (f. 21). "La pierre de taille de tout grain n'y est pas rare" (f. 2). "Les chardons ne sont pas rares; il y en a de toutes les espèces" (f. 9). Sometimes on the contrary the term is applied to things that are abundant: Chipmunks are "ces rares animaux," although one sees "des grandes bandes" of them (f. 50). In the case of the capillaire, "Ce simple est un des plus rares et un des plus recherchés de tout le pays. Ce n'est pas qu'il n'y en ait beaucoup dans tous les bois, mais il est précieux pour cette vertu qu'il a de rafraîchir la poitrine" (f. 12).

In translating rare, we have used the corresponding English term "rare" where that seems to be the sense. In other cases, we have used other words such as "fine." A similar approach has been used for the adjective beau, which is translated as "beautiful," "fine" or another word, depending on the context, and curieux, which like the English "curious" at the time could have many senses including "odd," "unusual" or "interesting."

Another frequent adjective is admirable, sometimes in the present-day sense of laudable, at other times in the older sense of surprising or astonishing. ${ }^{9}$ Among the many things Nicolas finds admirables one may mention the firefly, porcupine quills, the compartments of a beaver lodge, the size of the large trout, the cries of bears in their den, and the fact that the flying squirrel's "wings" are covered with hair like the rest of its body. But admirable things are not limited to the New World. Nicolas cannot resist telling a story of two finches in France which he considers more admirable than anything else he has to say about birds. ${ }^{10}$ 
The practices of native people include many admirable things. Among them are stews made of fat from moose intestines (f.99), the way of hunting the tigre marin by using arrows attached to a hide rope (f. 121), and the technique of catching white fish by using nets spread out under the ice (f. 179). Nicolas admires (in our modern sense) the hunting and fishing techniques in question, but from his description of the stew, one may guess that he does not find it appetizing. He writes of the moose intestine: "Les Indiennes ne font que le presser un peu pour en faire sortir, vous m'entendez bien, et sans prendre la peine de le laver, elles le tortillent pour le faire cuire de la manière dont je donne ici la figure." For admirable as for rare and other adjectives, we have tried to understand the meaning and to supply an appropriate word, often "admirable" but sometimes another term such as "remarkable."

We have mentioned that the Histoire naturelle discusses plants, animals, birds and fish. The section on birds includes insects, which like birds live in the air; the one on fish includes aquatic mammals such as the whale and the porpoise, which are specifically referred to as poissons. This follows the principle of classification according to habitat. On the other hand Nicolas is quite aware of physiological differences between the different species. He says of the whale that "Ce poisson a des poumons, des reins, une vessie," and states that porpoises are born alive and are nursed by their mother.

This use of the French word poisson, like the English "fish," was normal for the time. The Thresor de la langue française (1606) mentions that poisson refers mainly to species with fins, but it also includes among its examples soft-fleshed animals such as the cuttlefish, shellfish such as oysters, and "Toute sorte de fort grand poisson, comme balaines." The 1694 Dictionnaire de l'Académie Française entry begins with the definition: "Animal qui naist, \& qui vit dans l'eau," and the same definition appears in the 1798 edition of this dictionary. Only in the 1835 edition do we see the more restricted modern definition: "Animal à sang rouge et froid, qui respire par des branchies, et qui naît et vit dans l'eau, où il se meut à l'aide de nageoires." Similarly, Samuel Johnson's Dictionary of the English Language (1775) defines "fish" as "An animal that inhabits the water," and quotes Shakespeare's reference in A Comedy of Errors to "The beasts, the fishes, and the winged fowls" (the same division by habitat that one sees in the Histoire naturelle). The Oxford Dictionary of the English Language (second edition, 1989) defines the word as used in popular language to refer to "any animal living exclusively in the water," whereas in modern scientific language, its meaning is "restricted to a class of vertebrate animals, provided with gills throughout life, and cold-blooded."

If marine mammals had been treated entirely separately from fish in the Histoire naturelle, a translator might consider calling them by some name such as "waterdwelling animals." However, they are included in the same section, in order: the halibut, the grey porpoise, the white porpoise, the shark (the title of the entry on this fish is "Du requiem, que le vulgaire ignorant appelle requin," f. 188), the small whale, and the large whale. The order of figures in the Codex is the same. Porpoises and whales come at the end of the section on fish not because of their anatomy, but because of their size, as Nicolas in the various sections begins with the smallest species and ends with the largest. ${ }^{11}$

In order to reflect the world view embodied in the text, we consider it necessary to retain the use of the same term for both fish and marine mammals, and therefore 
to call them all fish. We are thus following a different principle from that tentatively adopted for rare and admirable, where Nicolas' precise choice of words is not essential to his ideas.

Even a reader with a good general knowledge of seventeenth-century language and literature may have difficulty with specialized subject areas. A particularly hard part of the treatise to translate was the section on falconry. Although Nicolas states that falconry is not practiced in the New World, he nevertheless writes many pages about it, giving, as he says, "un extrait de tous les auteurs anciens et modernes." Some passages, such as the following, seem to have no purpose except to use as much terminology as possible:

Enfin, je ne saurais expliquer ni dire le plaisir que ressentent ceux qui se plaisent et qui s'attachent à la chasse de l'oiseau quand ils le voient écumer, c'est-à-dire épier son gibier, quand ils le remarquent s'écarter du déduit, s'y remettre, impiéter, fondre, giboyer, guinder, reguinder, lier, envelopper, partir, redonner, remettre, venir, voler, décocher, choquer, charger, charrier, brancher, motter, arrêter et faire tous les merveilleux effets d'un oiseau des mieux affaités. (f. 151)

The translator's difficulty is compounded because Nicolas really has nothing original to say about the subject. He states that New World birds would be suitable to be trained for falconry; but all the rest comes from the authors that he quotes from without specific acknowledgement.

A different kind of question arises from Nicolas' references to native people. The terms he uses include Americain or Ameriquain, Indien, habitant, coureur de bois, and other more limited or localized ones such as Huron, Virginien, Outtagami, Manataoué, and Outtaouak. However, he most frequently uses the terms sauvage and barbare, ${ }^{12}$ which pose problems for translators. Although these words could certainly be pejorative in the seventeenth century, they were not always so unfavourable as they seem today. Often Nicolas' usage is neutral. He describes for example "la fraise que les sauvages nomment le fruit du cour"; he writes of the blueberry that "Les sauvages en font partout des grandes provisions"; and he says of the maple: "lorsque les neiges sont fondues, l'arbre ne coule plus et ne donne plus à boire, ni aux sauvages ni aux Français." Barbare is also used in a neutral sense. Nicolas explains that la mer Tracy is the "grand lac Supérieur, que les barbares appellent le Grand Lac" (f. 2). In discussing the wood of the walnut tree, he says: "Les barbares s'en servent pour faire des arcs." Aware of the ambiguity of his vocabulary, he speaks with admiration of the way "ces barbares, qui n'ont que le nom de sauvages," make ropes of moose skin (f. 96). On the other hand, he sometimes does use the terms in an unfavourable way: "Nos barbares Indiens, quoique les plus sauvages du monde, se croyant les plus nobles des hommes, n'ont point de plus forte inclination après celle de la guerre que de se rendre parfaits dans le noble exercice de la chasse où ils se plaisent infiniment" (f. 126). The irony here is double-edged; while primarily directed at native people, it also touches the European nobility and their occupations.

The French word sauvage and the English "savage" are not symmetrical. The meaning of the French word has changed less than the English one from Latin silvaticus (of the forest). The bilingual Robert et Collins Senior dictionary (1993) gives as English equivalents of the French sauvage: "wild," "savage," "unsociable," "unauthorized," etc. Thus a wild flower is une fleur sauvage, an unsociable man is un 
homme sauvage, and unauthorized camping is du camping sauvage. Vivre en sauvage means, according to this dictionary, "to live a secluded life, live as a recluse." On the other hand, the French equivalents given for the English "savage" are brutal, méchant, féroce, virulent, furieux, colérique - all strongly pejorative terms. Readers of this article will recognize that "a savage crime" or "a savage attack" is a particularly cruel one. Other meanings of the French word, such as "not domesticated" or "uninhabited," are expressed in English by the adjective "wild." The word "savage" is thus a loaded term in English.

One of the most famous literary references to the sauvage occurs in Montaigne's essay "Des cannibales." The author takes advantage of the double nature of the word and its reference both to natural species and to human beings:

Or je trouve, pour revenir à mon propos, qu'il n'y a rien de barbare et de sauvage en cette nation, à ce qu'on m'a rapporté, sinon que chacun appelle barbarie ce qui n'est pas de son usage [...] Ils sont sauvages, de mesme que nous apellons sauvages les fruicts que nature, de soy et de son progrez ordinaire, a produicts: là où, à la vérité, ce sont ceux que nous avons alterez par nostre artifice et detournez de l'ordre commun, que nous devrions appeller plustot sauvages. (Montaigne 1969, p. 254)

This play on the different senses of the word proves to be a challenge for translators. In order to keep the symmetry, John Florio, the first translator of Montaigne, is forced into the unusual description of fruits as "savage":

They are even savage, as we call those fruits wilde which nature of her selfe and of her ordinary progresse hath produced: whereas indeed, they are those which our selves have altered by our artificiall devices, and diverted from their common order, we should rather terme savage. (Montaigne 1885, p. 94)

Charles Cotton's version avoids this at the cost of losing the word play:

They are savages at the same rate that we say fruits are wild, which nature produces of herself and by her own ordinary progress; whereas, in truth, we ought rather to call those wild whose natures we have changed by our artifice and diverted from the common order. (Montaigne 1923, p. 34)

Jacob Zeitlin's treatment is similar:

They are savages in the same sense that we say fruits are wild, which nature produces by herself and in her usual course; whereas in truth we ought rather to call wild those whose natures we have changed by our artifice and diverted from the common order. (Montaigne 1936, p. 181-182)

Donald Frame chooses "wild" for all occurrences of sauvage in the sentence:

Those people are wild, just as we call wild the fruits that Nature has produced by herself in her normal course; whereas really it is those that we have changed artificially and led astray from the common order, that we should rather call wild. (Montaigne 1957, p. 152)

M. A. Screech, like Florio is intent on capturing the word play: ${ }^{13}$

Those 'savages' are only wild in the sense that we call fruits wild when they are produced by Nature in her ordinary course: whereas it is fruit which we have artificially perverted and misled from the common order which we ought to call savage. (Montaigne 1991, p. 231) 
Although Florio and Screech make the most visible effort with sauvage, none of the translators succeeds completely in joining the two meanings.

As Dickason (Dickason 1984, p. 17-22 and 70-80) and Gagnon (Gagnon 1984, p. 20-27; see also Gagnon and Petel 1986) point out, many Europeans still held the medieval idea of the "wild man" as a hairy, apelike human, and expected to find such beings in the New World. For this reason, explorers and other writers stressed in their accounts that the people they had seen were well-formed and, contrary to expectations, had very little hair on their bodies. Once this information became widely known - and it took several centuries for it to replace even partially the earlier images of a human being seen as inferior - a different pre-existing stereotype came into play. Native people of the Americas came to be identified by some writers with the primitive innocence that was supposed to have characterized the earliest times of human existence. This idea finds expression in Lafiteau's title Moeurs des sauvages américains comparées aux moeurs des premiers temps (Lafiteau 1983), in Montaine's essay quoted above, and later in the writings of Rousseau, particularly the Discours sur l'origine et les fondements de l'inégalité parmi les hommes (1755). Whether they fully believed in it or not, many writers used the picture of the savage, close to nature and uncorrupted by the vices of civilization, to criticize the faults of Europe. In Lahontan's 1703 Suite du voyage de l'Amérique, the savage Adario points out the inconsistencies of Christianity to his interlocutor Lahontan (Lahontan 1990, vol. 2; see Ouellet's Introduction, vol. 1). In the eighteenth century, Voltaire has the Huron hero of his novel L'Ingénu (1767) satirize French society, religion and government in the name of reason. In Diderot's Supplément au voyage de Bougainville (1796), the supposedly natural sexual mores of Tahiti are contrasted with the repressed sexuality of Europe.

English writers as well as French ones were intrigued by the contrast between inhabitants of the Old and the New Worlds. In seventeenth- and eighteenth-century English, the word "savage" was sometimes applied to people considered to be less advanced than Europeans. Athough often pejorative, the term could be neutral or even favourable, as in the expression "noble savage." However, seventeenth-century English writers - particularly those who dealt directly with aboriginal people - were less likely to refer to these people as savages than were French writers. To take a sample of contemporary works in English, Thomas Harriot calls them "the inhabitants" or "the natural inhabitants" (Harriot 1588); John White (White, J. 1588), Bartholomew Gosnold (Gosnold1602), John Smith (Smith n.d.) and William Strachey (Strachey1612) refer to "the inhabitants"; Gabriel Archer (Archer 1602), Strachey, Andrew White (White, A. 1640), Roger Williams (Williams1973, orig. $1643)^{14}$ and George Fox (Fox 1672) say "Indians." Other terms are used, sometimes by the same writers: Williams says "natives," Smith "the people," "the naturals" and "the country people." "Savages," although not so frequent as the French sauvages, is used by Archer, Raphe Harmor (Harmor 1615), John White, Smith (Smith 1624. and Smith n.d.), and occasionally by Harriot and Strachey.

In the course of the twentieth century, both "savages" and "Indians" have been used by translators. Sauvages is rendered as "savages" in Annie N. Bourne's translation of Champlain's Voyages de la Nouvelle France occidentale, dite Canada,1632 (Champlain 1911), in Reuben Gold Thwaites' translation of the Relations des Jésuites (Jesuit Relations 1896-1901) and in the extracts published subsequently (Jesuit Relations 1925, 
and other editions), in H. H. Langton's translation of Sagard's Grand Voyage au pays des Hurons, 1632 (Sagard 1939), and in the translation of Thevet's 1586 Grand insulaire by Roger Schlesinger and Arthur P. Stabler (Thevet 1986). "Indians" is chosen in William F. Ganong's English version of Le Clercq's Nouvelle Relation de la Gaspesie, 1591 (Le Clercq 1910), Mrs. Clarence Webster's version of Dièreville's Relation du voyage du Port Royal de l'Acadie ou de la Nouvelle France, 1708 (Dièreville 1933), and W. N. Fenton and E. L. Moore's version of Lafiteau's Moeurs des sauvages américain comparées aux moeurs des premiers temps, 1724 (Lafiteau 1974). This sample thus includes four translators between 1896 and 1986 who choose "savages" and three from 1910 to 1974 who choose "Indians."

In the case of the Histoire naturelle one could argue for using "Indians" for Nicolas' sauvages, since it does correspond to one of his synonyms. However, English usage has continued to change, and "Indian" is no longer so universally accepted as it was a few decades ago. In many contexts now, "Aboriginal" or "First Nations" is preferred. As these terms would be visibly anachronistic in a seventeenth-century text, we have not used them. Our choice of "savage" and "barbarian," though it might appear to be a simple reflex, was in fact made after much weighing of alternative possibilities. The use of the term in Nicolas' work will be explained in a note.

Although it is not primarily a problem of translation, identifying the various species of animals, plants, birds and fish mentioned in the Histoire naturelle is an enormous challenge. The task requires the knowledge and participation of experts in the various areas of natural history. ${ }^{16}$ Nicolas often calls things by the name of the closest species in Europe, and says that the local one is similar, or how it is different. In such cases, we keep close to Nicolas' expressions. The citronnier becomes the "lemon" although it is not what we mean by that term today; the écureuil jaune is the "yellow squirrel," with a note that this is now called the red squirrel. In a number of cases definite identification is not possible. For example, Nicolas refers to a bird that he calls l'oiseau mort nommé Tchipai-zen, believed by native people to be the soul of a dead person. This bird has a remarkable song, but as it is seen only at a distance in the woods, he cannot give a precise description of it. We use the expression "dead bird" in the text, although one can guess it may be the whip-poor-will. The enfant $d u$ diable, or devil's child, is probably the wolverine. Such questions are discussed in notes.

Whatever translators do, they run the risk of falsifying or even betraying the author. In translation the Histoire naturelle we choose various strategies depending on the material involved. In most cases we follow Nicolas' wording closely, as the purpose of the translation - to make Nicolas' work and thought available to readers today - is different from that of Nicolas - to make the flora and fauna of Nouvelle France known to the French reader of his time. We use various words to translate beau, rare and admirable, as we understand the meaning from context. On the other hand we keep "fish" for poisson, at the risk of giving a false impression of Nicolas' knowledge. We use "savage" and "barbarian," although this may make Nicolas seem more eurocentric and racist than he is. We hope that readers will avoid the temptation of thinking that people of the past were necessarily morally unenlightened by comparison with our superior views. It is quite true that Nicolas holds prejudices in favour of Europe and European culture. Without doubt, being a missionary, he considers Christianity to be the one true religion. He refers to certain beliefs and practices of 
native people as "aveuglement" (f. 37), "leur jonglerie" (f. 124) and "danses ... superstitieuses" (f. 125). However, these views are to some extent balanced by those expressed in many places in the Histoire naturelle. It is a challenge for translators, editors and readers today to provide a more nuanced understanding by placing his writings in the intellectual and linguistic context of his time.

\section{NOTES}

1. An earlier version of this paper was presented at the 2003 Congress of the Canadian Society of Translation Studies.

2. Under the direction of François-Marc Gagnon, with English translation by Nancy Senior and Wayne Hudson.

The original manuscript of the Histoire naturelle is in the Bibliothèque Nationale de France; the National Archives of Canada has a microfilm copy. The standard French text with modernized spelling, used here, was established by Réal Ouellet and accompanied by a very useful glossary of seventeenth-century terms. We have also used a transcription by Auguste Vachon, revised by Roch Samson, which reproduces Nicolas' original spelling and punctuation.

3. Gagnon (unpub.) points out that Nicolas uses a system of classification by habitat, based on the four elements of Greek science (earth, air, fire and water) that is found in the works of Aristotle. Aristotle was aware that the absence of animals living in fire was a problem.

4. William F. Ganong, translator of Leclercq's Nouvelle Relation de la Gaspesie (first published in French in 1691), draws a practical conclusion from this long-standing debate:

"A translator, as I have found, can never please everybody. Some would have him render the original, regardless of its literary merits, into a book of clear and flowing English: others hold that the original should be followed just as literally as clearness will permit, while many insist that only a middle course is suitable. I have considered that this multiplicity of opinions leaves me free to please myself, and accordingly I have tried to make just such a translation as I like to read, viz., one which renders clearly the meaning of the original while retaining as much as possible of its flavour." ( Leclercq 1910, p. viii)

5. Although often useful, this approach has its dangers, as readers may build an interpretation on words supplied by the translator. On one occasion, a graduate thesis made much of the expression "the common herd," supposedly used by Rousseau in The Social Contract to refer to the common people. In other parts of the original French passage, Rousseau uses le vulgaire and le peuple, neither of which was in eighteenth-century French as contemptuous as "the common herd"; and at the place where the translator uses this English expression, Rousseau uses no noun at all. (Le Contrat social, Flammarion, 1996 and The Social Contract, tr. Maurice Cranston. Harmondsworth, Middlesex, Penguin Books, 1968)

6. This quotation is given with the original spelling and punctuation. All subsequent quotations use Ouellet's modernized version.

7. (To tell you now why I have described this plant so well, you should know that one day I was lost with one Frenchman in the woods and the great meadows of Virginia, where the grass was almost a quarter of a pike high. I was starving, along with my dear companion, who the day before I found the lemons, had fainted twice. We were starving, having eaten hardly anything for several days, and had spent the night beside a beaver dam sleeping on the ground, without covers and without food. The next day, dragging ourselves miserably through the woods to try to find our way again, we fortunately came into a great woods and then into meadows as far as the eye could see that we had seen from the top of a mountain. We found some of the lemons that I have described, with blackberries. We ate a large amount and gathered enough for several days.)

8. This pomme de terre has nothing to do with the potato. The word pomme is used in the general sense of "fruit," and this low-growing (thus de terre) fruit is probably the cranberry.

9. The Dictionnaire de l'Académie Française gives the following definition of the verb admirer in its 1694 and 1798 editions: "Considérer avec surprise, avec estonnement une chose qui est extraordinaire en quelque manière que ce soit" (emphasis added). Only in the 1835 edition is the definition limited to a favourable sense: "Considérer avec un étonnement mêlé de plaisir, ce qui paraît beau, ce qui parait merveilleux." 
10. A wild goldfinch became enamoured of a tame one kept in a cage in a monastery, and the two male birds became devoted to each other, giving caresses with their beaks through the bars of the cage. Despite all efforts of the monks, nothing succeeded in separating them, and finally they were given to the General of the order. Nicolas concludes: "Ma plume ne peut pas expliquer tout ce que j'ai vu d'admirable là-dessus" (f. 132). It is not clear whether Nicolas considers the devotion of these birds to be laudable or simply unusual. For this passage, we have tentatively settled on the word "remarkable," which could suggest either meaning.

11. There are some exceptions to this order. Birds are divided into land birds, water birds, and birds of prey; within each of these groups they are treated in order of size, in Nicolas' usual manner.

12. Nicolas uses sauvage(s) 154 times as a noun or adjective referring to the people or their language (that is, not counting descriptions of wild plants or animals such as la fraise sauvage, le boeuf sauvage); sauvagesse(s) is used 5 times and sauvageons once, for a total of 160 . He uses barbare(s) 27 times; Indien(s) 28 times and Indienne(s) 8 times, for a total of 36; Américain(s) 39 times and Américaines twice for a total of 41. In sum, various forms of sauvage and of barbare together are used 187 times; forms of Indien and Américain, 77 times.

Some writers distinguish between two stages of civilization, the savage state being more primitive than the barbarous one. Nicolas does not make such a distinction; he uses the two terms synonymously, along with the other ones mentioned.

13. Screech writes: "I have tried to convey Montaigne's sense and something of his style, without archaisms but without forcing him into unsuitable, demotic English. I have not found that his meaning is more loyally conveyed by clinging in English to the grammar and construction of his French: French and English achieve their literary effect by different means. On the other hand I have tried to translate his puns: they clearly mattered to him, and it was fun doing so" (Montaigne 1991, p. lii).

14. Although his own terms are "Indians" and "natives," Williams does refer ironically to the use of other words by other European settlers. He writes: "It is a strange truth that a man shall generally find more free entertainment and refreshing among these Barbarians, than amongst thousands that call themselves Christians" (Williams 1963, p. 46). In 1635, Williams was expelled from the Massachusetts colony because, as well as advocating complete freedom of religion, he maintained that the land belonged to the native people and could not be transferred to settlers by a charter from the king. During the time of exile he was kindly treated by Narragansett Indians.

15. Although Thwaites uses the term "savages" to reflect the authors' French usage in the Relations des Jésuites, when speaking in his own voice in the introduction he usually says "Indians." More recently, no doubt as a result of concerns about the connotations of "savages," the translators of Lafiteau's Moeurs des sauvages ameriquains explain: "Sauvages we have rendered 'Indians' because it has come to be the generic term for the aborigines of the New World and their descendents." Their English title is thus Customs of the American Indians.

The reverse has occurred in the case of Jacques Cartier's Voyages. H. P. Biggar's translation, published in 1924, renders sauvages (or in Cartier's spelling, sauvaiges) as "Indians" or uses other terms depending on the context. Sometimes femme becomes "woman," occasionally "squaw." In a 1993 English edition of the Voyages, the introduction by Ramsay Cook states that the translation is that of Biggar with the exception of "some minor but interesting alterations and corrections." According to Cook, 'Cartier never used the words 'Indian', 'squaw', 'chief', 'tribe', or 'wigwam'. On those occasions where Biggar used them I have reverted to translations of Cartier's terms: 'sauvaige', 'homme', 'gens du pays', 'femme', 'peuple', 'seigneur', 'maison'. These words better express Cartier's outlook and, in some cases, our own” (Cartier 1993, p. vii-viii).

16. Stuart Houston and Henry Reeves have been particularly helpful in this work.

\section{REFERENCES}

\section{Original works and translations}

Archer, G. (1602): The Relations of Captain Gosnold's Voyage to the North Part of Virginia. See Virtual Jamestown.

Cartier, J. (1924): The Voyages of Jacques Cartier, translations, notes and appendices by H. P. Biggar, Ottawa, F. A. Acland.

Cartier, J. (1993): The Voyages of Jacques Cartier, introduction by Ramsay Cook, Toronto, Buffalo, London, University of Toronto Press. 
Cartier, J. (2000): Voyages au Canada, introduction de Marie Hélène Fraïssé, Montréal, Comeau \& Nadeau. (First pub. 1632)

Champlain, S. de (1911): The Voyages and Explorations of Samuel de Champlain (1604-1616) Narrated by himself, translated by Annie Nettleton Bourne, edited with introduction by Edward Gaylord Bourne, 2 vols, Toronto, The Courier Press.

Dièreville (or Diéreville) (1933): Relation of the Voyage to Port Royal in Acadia or New France, by the Sieur de Dièreville. Translated by Mrs. Clarence Webster, edited with notes and introduction by John Clarence Webster, Toronto, the Champlain Society.

Dièreville (or Diéreville) (1997): Relation du voyage du Port Royal de l'Acadie ou de la Nouvelle France; suivie de poésies diverses, édition critique par Normand Doiron, Montréal, Presses de l'Université de Montréal. (First pub. 1708)

Fox, G. (1672): Travels in Virginia and North Carolina, <http://smith2.sewanee.edu/gsmith/ courses/Religion391/DocsEarlySouth/1672-GeorgeFox.html>.

Gosnold, B. (1602): "Master Bartholomew Gosnold's Letter to his Father, touching his first voyage to Virginia," in Virtual Jamestown.

Hamor, R. (1615): A True Discourse of the Present Estate of Virginia, Virtual Jamestown; see also extract in Wright (1965), p. 226-237.

Harriot (or Hariot), T. (1588): A Briefe and True Report of the New Found Land of Virginia, Virtual Jamestown; see also extract in Wright (1965), p. 115-133.

Jesuit Relations and Allied Documents (1896-1901), edited and translated by Reuben Gold Thwaites, 73 vols, Cleveland, Burrows.

Jesuit Relations and Allied Documents (1925), with an introduction by Reuben Gold Thwaites, McClelland \& Stewart, Toronto.

Lafiteau, J.-F. (1974): Customs of the American Indians Compared with the Customs of Primitive Times, edited and translated by William F. Fenton and Elizabeth L. Moore, 2 vols Toronto, The Champlain Society.

Lafiteau, J.-F. (1983): Moeurs des sauvages américains comparées aux moeurs des premiers temps, introduction, choix des textes et notes par Edna Hindie Lemay, François Maspero, Paris. (First pub. 1724)

Lahontan (1990): Oeuvres complètes, edition critique par Réal Ouellet avec Alain Beaulieu, Bibliothèque du Nouveau Monde, Montréal, Presses de l'Université de Montréal, 2 vols. (First pub. of Lahontan 1702-3)

Le Clerce, C. (1910): New Relation of Gaspesia, with the Customs and Religion of the Gaspesian Indian, translated and edited, with a reprint of the original, by William F. Ganong, Toronto, The Champlain Society. (First pub. of Nouvelle relation 1691)

Montaigne, M. de (n.d.): The Essayes of Michael Lord of Montaigne, translated by John Florio, London and New York, George Routledge and Sons.

Montaigne, M. (1923): Essays of Montaigne, translated by Charles Cotton, edited by William Carew Hazlitt, vol. 2, London, the Navarre Society Limited.

Montaigne, M. (1936): The Essays of Michel de Montaigne, translated and edited by Jacob Zeitlin, vol. 2, New York, Alfred A. Knopf.

Montaigne, M. (1957): The Complete Works of Montaigne, translated by Donald M. Frame, Stanford, California, Stanford University Press.

Montaigne, M. (1969): Essais, chronologie et introduction par Alexandre Micha, Paris, GF Flammarion.

Montaigne, M. (1991): The Essays of Michel de Montaigne, translated and edited, introduction and notes by M. A. Screech, London, The Penguin Press.

Nicolas, L. (n.d.): Histoire naturelle des Indes occidentales, Bibliothèque Nationale, Paris, Fonds français 24 225, Ancien oratoire 162. A microfilm copy is in the National Archives of Canada, F-567.

Nicolas, L. (n.d.): Raretés des Indes or Codex Canadiensis, manuscript at the Thomas Gilcrease Institute of American History and Art, Tulsa, Oklahoma. 
Nicolas, L. (n.d.): Traitté des animaux à quatre pieds terrestres et amphibies, qui se trouvent dans les Indes occidantales, en Amérique septentrionale, Bibliothèque Nationale de France, manuscrit français 12223. Copy, National Archives of Canada, MG 7 I A2, vol. 12223.

Nicolas, L. (1974): Les Raretés des Indes, Album manuscrit de la fin du XVII siècle [...] précédé d'un avant-propos par le baron Marc de Villiers, Montréal, Les Editions du Bouton d'Or. (Facsimile edition of the Raretés des Indes)

Nicolas, L. (1981): Codex du nord amériquain, Québek, 1701 (attributed to Charles Bécard, sieur de Grandville), Montréal, Média-Teq. (A small-format edition of the Raretés des Indes)

Nicolas, L. (1994): L'algonquin au XVII siècle. Une édition critique, analysée et commentée de la grammaire algonquine du père Louis Nicolas, Diane Daviault, ed., Sainte-Foy, Presses de l'Université du Québec, XVII.

Relations des Jésuites contenant ce qui s'est passé de plus remarquable dans les missions des pères de la Compagnie de Jesús dans la Nouvelle-France (1858), Québec, A Coté.

SAgard, G. (1939): The Long Journey to the Country of the Hurons, by Father Gabriel Sagard, introduction and notes by George M. Wrong, translated by H. H. Langton. Toronto, the Champlain Society.

SAgard, G. (1990): Le Grand Voyage du pays des Hurons, texte établi par Réal Ouellet, introduction et notes par Réal Ouellet et Jack Warwick, Québec, Bibliothèque québécoise. (First pub. 1632)

SмIтH, J. (n.d.; early 17th c,) "Instructions by Way of Advice, for the Intended Voyage to Virginia," Virtual Jamestown.

Sмiтн, J. (1624): General History of Virginia, extract in Wright 1965, p. 171-181.

Strachey, W. (1612): The History of Travel into Virginia Britannia, extract in Wright (1965), p. 206-219.

ThEvet (or Thévet), A. (1986): André Thévet's North America, A Sixteenth-Century View, editiontranslation, with notes and introduction, by Roger Schlesinger and Arthur P. Stabler, Kingston and Montreal, McGill-Queen's University Press.

Virtual Jamestown: First Hand Accounts of Virginia, 1575-1705, Crandall Shifflette 2000, <http:// etext.lib.virginia.edu/etcbin/jamestown-browse?id=J1009>. This site includes texts by sixteenth- and seventeenth-century writers, including Gabriel Archer, Bartholomew Gosnold, Thomas Harriot, Raphe Harmor, John Smith, John White.

White, A. (1640): “The Natural Disposition of the Indians," < http://smith2.sewanee.edu/gsmith/ courses/Religion391/DocsEarlySouth/1640-AndrewWhite.html>.

White, J. (1588): The True Pictures and Fashions of the People in that Parte of America now called Virginia, in Virtual Jamestown.

Williams, R. (1963). A Key into the Language of America, in Complete Writings, vol. 1. New York, Russell \& Russell.

Wright, L. B. (1965): The Elizabethans' America. A Collection of Early Reports by Englishmen in the New World, London, Edward Arnold.

\section{Secondary sources}

Berman, A. (1992): The Experience of the Foreign: Culture and Translation in Romantic Germany, translated by S. Heyvaert, Albany, State University of New York.

Dickason, O. (1984): The Myth of the Savage and the Beginnings of French Colonialism in the Americas, Edmonton, University of Alberta Press.

Doyon, P.-S. (1993), L'Iconographie botanique en Amérique Française du XVII au milieu du XVIII ${ }^{e}$ siècles, thèse de doctorat, Université de Montréal, $<$ http://www.uqtr.ca/arts/histoire/botanique/ entree.html>.

Hanzeli, V. (1969): Missionary Linguistics in New France, a Study of Seventeenth- and EighteenthCentury Descriptions of American Indian language, The Hague, Mouton.

Gagnon, F.-M. (1984): Ces hommes dits sauvages. L'histoire fascinante d'un préjugé qui remonte aux premiers découvreurs du Canada, Montréal, Éditions Libre Expression. 
Gagnon, F.-M.et D. Petel (1986): Hommes effarables et bestes sauvaiges: Images du NouveauMonde d'après les voyages de Jacques Cartier. Montréal, Boréal.

Gagnon, F.-M (unpublished). Introduction to Louis Nicolas, Histoire naturelle des Indes occidentales.

NidA, E. (1964): Toward a Science of Translating, Leiden, E. J. Brill.

Schleiermacher, F. (1977) "On the Different Methods of Translating," in André Lefevere, Translating Literature: The German tradition from Luther to Rosenzweig, Assen, Amsterdam, Van Gorcum, p. 66-89.

Seleskovich, D. and M. Lederer (1984): Interpréter pour traduire, Paris, Didier.

Sioui, A.-M. (1979): “Qui est l'auteur du Codex canadiensis?," Recherches amérindiennes, vol. VIII, no 4 , p. 271-279.

Tremblay, G. (1983): Louis Nicolas: sa vie et son oeuvre. Les divers modes de transport des Indiens Américains, mémoire de maîtrise, Département d'Histoire, Université de Montréal. 